\title{
Prevalence of musculoskeletal disorders and rheumatic disease in the Warao, Kari'ña, and Chaima indigenous populations of Monagas State, Venezuela
}

\author{
Ysabel Granados $^{1,2} \cdot$ Celenia Rosillo $^{3} \cdot$ Ligia Cedeño $^{3}$ - Yanira Martínez ${ }^{4}$. \\ Gloris Sánchez $^{5}$ - Geovalis López ${ }^{3}$ - Fernando Pérez ${ }^{6}$ - Damarys Martínez ${ }^{3}$. \\ Gabriela Maestre $^{3} \cdot$ Sol Berbin $^{1} \cdot$ Rosa Chacón $^{7} \cdot$ Iván Stekman $^{8} \cdot$ Evart Valls $^{9}$ • \\ Ingris Peláez-Ballestas ${ }^{10}$
}

Received: 14 May 2015 / Revised: 25 November 2015 / Accepted: 14 January 2016/Published online: 19 February 2016

(C) The Author(s) 2016. This article is published with open access at Springerlink.com

\begin{abstract}
This study aimed to estimate the prevalence of musculoskeletal disorders and rheumatic diseases in the Warao, Kari'ña, and Chaima indigenous populations of Monagas State, Venezuela. A cross-sectional, analytical, community-based study was conducted in 1537 indigenous subjects $\geq 18$ years old ( $38.6 \%$ male, mean age 41.4 \pm 17.5 years). The cross-culturally validated Community Oriented Program for the Control of Rheumatic Diseases (COPCORD) diagnostic questionnaire was applied. Subjects with a positive COPCORD diagnosis (either historic or current pain) were evaluated by primary care physicians and
\end{abstract}

Ysabel Granados

ymgranados@gmail.com

1 Rheumatology Unit, Hospital Dr. Manuel Núñez Tovar, Maturín, Monagas, Venezuela

2 Centro Medico, $5^{\circ}$ Piso Consultorio 4, Sector Las Avenidas, Maturín, Estado Monagas 6201, Venezuela

3 Health Network "Barrio Adentro", Ministerio del Poder Popular para la Salud, Estado Monagas, Venezuela

4 Rheumatology Unit, Hospital Central de Maracay, Maracay, Venezuela

5 IVSS “Dr. Cesar Rodríguez”, Puerto La Cruz, Venezuela

6 Hospital "Dr. José A. Urrestarazu”, Caripe, Estado Monagas, Venezuela

7 Private Clinical Center, Caracas, Venezuela

8 Hospital Universitario de Caracas, Caracas, Venezuela

9 Health Indigenous Department, Estado Monagas, Venezuela

10 Rheumatology Unit, Hospital General de Mexico "Dr. Eduardo Liceaga”, Mexico City, Mexico rheumatologists. A descriptive analysis was performed and comparisons made using analysis of variance and the chisquare test. Pain in the last 7 days was reported by $32.9 \%$, with pain intensity, according to a Likert-type scale [no pain, 195 (38.5\%); minimal pain, 231 (45.6\%); strong pain, 68 (13.4\%); intense pain, $5(0.9 \%)], 38.0 \%$ reported historical pain, and 641 (41.7\%) had either historic or current pain. Of the COPCORD-positive subjects, pain most frequently occurred in the knee, back, and hands. Musculoskeletal and rheumatic diseases included osteoarthritis (14.1\%), back pain (12.4\%), rheumatic regional pain syndromes (RRPS) (9.7\%), undifferentiated arthritis $(1.5 \%)$, rheumatoid arthritis (1.1\%), and fibromyalgia $(0.5 \%)$. Chaima $(18.3 \%)$ and Kari'ña $(15.6 \%)$ subjects had a high prevalence of osteoarthritis, and Warao subjects had a high prevalence of low back pain $(13.8 \%)$. The prevalence of RRPS was high in all three ethnic groups. The Chaima group had the highest prevalence of rheumatic diseases, with $2.0 \%$ having rheumatoid arthritis. This study provides useful information for health care policymaking in indigenous communities.

Keywords Indigenous populations $\cdot$ Musculoskeletal diseases $\cdot$ Prevalence $\cdot$ Rheumatic diseases $\cdot$ Venezuela

\section{Introduction}

The prevalence and severity of rheumatic diseases and musculoskeletal (MSK) disorders may vary according to ethnicity and socioeconomic conditions [1,2]. Genetic and epidemiological studies have indicated that certain rheumatic conditions may have greater prevalence and severity in specific indigenous groups [3]. Indigenous populations are 
numerically small and have diverse genetic and cultural characteristics [4]. The expansion of Westernized societies to their communities and historically established territories [5] constitutes a serious threat to their cultural heritage and lifestyles, which may have a negative influence on the health of these communities. The impact of chronic diseases on overall health is still unknown in many countries with indigenous populations, such as in Latin American countries.

Venezuela has 30 million inhabitants [6], with 724,592 indigenous subjects divided into 34 ethnic groups in 10 of the 23 states in the country. The State of Monagas located in eastern Venezuela has 17,898 indigenous (3.6\% of the state's total population) grouped into three ethnicities (Warao, Kari'ña, and Chaima) [7]. The main causes of mortality in these groups are known [8], but there is little epidemiological information about the impact of MSK disorders and rheumatic diseases on these populations, although these are among the most prevalent chronic and disabling conditions in medical practice [9].

The Community Oriented Program for the Control of Rheumatic Diseases (COPCORD) questionnaire has been developed as a means of estimating the prevalence of rheumatic diseases [10] and MSK pain in various regions of the world $[11,12]$. This methodology arose from an initiative by the International League of Associations for Rheumatology and the World Health Organization (WHO) to increase research on these chronic diseases in rural, urban, or marginal minority communities [13].

Epidemiological studies in indigenous populations need to overcome limitations such as community distrust, limited access to primary health care, and barriers to participation arising from beliefs, cultures, and languages [14, 15]. These limitations, however, should not deter the conduction of health studies, which can provide evidence for the development of culturally sensitive health policies. Thus, the objective of this study was to use the COPCORD methodology in order to estimate the prevalence of MSK disorders and rheumatic diseases in the Warao, Kari'ña, and Chaima indigenous people of Monagas State, Venezuela.

\section{Material and methods}

\section{Design and population}

A cross-sectional, descriptive, community-based study was performed in natives $\geq 18$ years of age in the Warao, Kari'ña, and Chaima indigenous groups in Monagas State, Venezuela. Subjects were defined as indigenous if they were descended from indigenous people, lived in the indicated geographical area, and maintained the cultural, social, and economic identity of his/her people or community, even when adopting elements from other cultures [16]. The sample was based on a community census

The Warao are the largest ethnic group in Monagas and the second largest in Venezuela [17]. They have inhabited the Orinoco River delta for over 8000 years and maintain their language and many of their ancient customs. They form a peaceful society of fishermen and harvesters settled in communities that are mostly only reached by boat. The Kari'ña inhabit the eastern plains and jungle regions of Bolivar district [18]. In Monagas, there is a population of 1174 who retain their native customs and language. Agriculture is their main livelihood, and they are adept craftsmen, making baskets and hammocks. The Chaima live in inaccessible mountainous areas [19] in the Turumiquire Mountains of the Andean coastal system [20], where they farm and produce handicrafts. The Chaima identity had become obscured and their language was in serious danger of extinction, but in the last two decades, a recovery and ethnogenesis process has been initiated.

\section{Instrument}

The cross-culturally validated COPCORD questionnaire adapted for Venezuela [21, 22] was applied. The questionnaires were administered in a door-to-door survey by primary care physicians, accompanied by previously trained indigenous male nurses from the respective ethnic groups, who were bilingual. All natives $\geq 18$ years old who had lived in their community for more than 6 months at the time of the study were surveyed.

\section{Identification of cases with musculoskeletal disorders}

The questionnaire included questions related to symptoms (pain, stiffness, and disability), treatment, adaptation to the problem, medical help sought, and non-conventional medicine use. The COPCORD questionnaire was considered positive when the participant subject reported MSK pain during the last 7 days and/or a history of pain.

\section{Clinical evaluation}

All COPCORD-positive individuals were evaluated in duplicate, by primary care physicians and certified rheumatologists. The American College of Rheumatology criteria were used for the diagnosis of osteoarthritis of the hands and knees [23, 24], rheumatoid arthritis [25], fibromyalgia [26], and systemic lupus erythematosus [27]. The Wallace criteria for diagnosis of gout [28], the modified New York criteria for ankylosing spondylitis [29], and the Southampton Group criteria for rheumatic regional pain syndromes (RRPS) [30] were used. Any non-specific joint or muscle pain, or those not meeting the classification criteria, were designated as MSK disorders and classified according to the WHO International 
Classification of Diseases version 10 [31]. The administration of the instrument and the evaluation of the COPCORDpositive patients were performed on the same day. If the patient required laboratory tests or a radiological study, he/she was referred to the Rheumatology Unit of Hospital "Dr. Manuel Núñez Tovar" in Maturín, Monagas State.

\section{Ethics}

The study was approved by the Ethics and Research Committee of the University Hospital "Dr. Manuel Núñez Tovar" and by representatives of the indigenous communities, thus complying with the provisions of the Communities and Indigenous Peoples Organic Law of the Bolivarian Republic of Venezuela [16]. All participants were informed about the study and gave their consent for use of their anonymized data.

\section{Statistical analysis}

Microsoft Access for Windows was used for collection of the encoded information, followed by data cleanup, and an exploratory analysis of the variables. This reported the distribution of continuous variables, and absolute and relative ordinal, nominal, or categorical frequencies. A bivariate analysis was performed on each of the study variables. One-way or twoway analysis of variance was used for comparisons of continuous variables and the chi-square test for ordinal, nominal, or categorical variables. The statistical analysis package STATA 11 (Stata Corp., College Station, TX, USA) was used.

\section{Results}

A total of 1537 subjects (100\% response rate) took part in the survey, including 943 (61.4\%) women and 594 (38.6\%) men with a mean age ( \pm standard deviation) of $41.4 \pm 17.5$ years. The mean duration of education was $4.5 \pm 4.4$ years; $21.1 \%$ were peasants, $17.7 \%$ were housewives, $16.6 \%$ were artisans, and $1.5 \%$ were teachers. Only $0.3 \%$ were professionals (Table 1). The Chaima group was mainly engaged in farming, often transporting heavy goods on their heads, shoulders, or backs through mountainous terrain. The Kari'ña were characterized by their handicraft work (fabrics), as were the Warao; thus, they undertook more repetitive movements and less physical activity.

\section{Pain characteristics}

Pain in the last 7 days was reported by 505 (32.9 \%) subjects; 584 subjects $(38.0 \%)$ had suffered pain at some time in their life (historic), and 641 (41.7\%) had either historic or current pain (COPCORD-positive). Pain intensity in the last 7 days was reported in a Likert-type scale, as follows: no pain, 195
Table 1 Population's social-demographic data $(n=1537)$

\begin{tabular}{|c|c|}
\hline Demographic characteristics & $(n=1537)$ \\
\hline \multicolumn{2}{|l|}{ Gender, $n(\%)$} \\
\hline Female & $943(61.4)$ \\
\hline Male & $594(38.6)$ \\
\hline Age, average (DE; range) & $41.4(17.5 ; 18-96)$ \\
\hline Schooling, average (DE; range) & $4.5(4.4 ; 0-16)$ \\
\hline \multicolumn{2}{|l|}{ Marital status, $n(\%)$} \\
\hline Single & $262(17.0)$ \\
\hline Married/free union & $1063(69.1)$ \\
\hline Widower & $30(1.9)$ \\
\hline Separated & $182(11.8)$ \\
\hline \multicolumn{2}{|l|}{ Ethnic group, $n(\%)$} \\
\hline Chaima & $692(45.0)$ \\
\hline Kari'ña & $262(17.0)$ \\
\hline Warao & $583(37.9)$ \\
\hline \multicolumn{2}{|l|}{ Language, $n(\%)$} \\
\hline Spanish & $1429(92.7)$ \\
\hline Native language & $621(40.4)$ \\
\hline \multicolumn{2}{|l|}{ Kinship, $n(\%)$} \\
\hline Indigenous father & $1306(84.9)$ \\
\hline Indigenous mother & $1437(93.4)$ \\
\hline Work (yes), $n(\%)$ & $951(61.8)$ \\
\hline \multicolumn{2}{|l|}{ Occupation, $n(\%)(n=1400)$} \\
\hline Peasant & $296(21.1)$ \\
\hline Housewife & $248(17.7)$ \\
\hline Artisan & $233(16.6)$ \\
\hline None & $202(14.4)$ \\
\hline Non-specified workers & $100(7.1)$ \\
\hline Laborer & $81(5.7)$ \\
\hline Fisherman & $74(5.2)$ \\
\hline Businessman & $55(3.9)$ \\
\hline Domestic service & $44(3.1)$ \\
\hline Others $^{\mathrm{a}}$ & $24(1.7)$ \\
\hline Teacher & $21(1.5)$ \\
\hline Technicians & $17(1.2)$ \\
\hline Professionals & $5(0.3)$ \\
\hline \multicolumn{2}{|l|}{ Physical activity } \\
\hline Load over 4 kg (8.82 lb) & $486(31.6)$ \\
\hline Repeatability & $345(22.4)$ \\
\hline
\end{tabular}

${ }^{\mathrm{a}}$ Seamstress, administrative workers; DE (abbreviation)

(38.5\%); minimal pain, 231 (45.6\%); strong pain, 68 $(13.4 \%)$; and intense pain, $5(0.9 \%)$, with a median score of 0 and interquartile range of 0 to 0.2 (Table 2). The treatments administered were as follow: non-steroidal anti-inflammatory drugs $276 / 382(72.2 \%$ ), analgesics 61/382 (15.9\%), and 7/382 $(1.5 \%)$ received disease-modifying antirheumatic drugs.

The most common sites of MSK pain were the knee, lumbar spine, hands, and ankles (Fig. 1). Of the 641 COPCORD- 
Table 2 Social-demographic characteristics and musculoskeletal pain prevalence by indigenous group

\begin{tabular}{|c|c|c|c|c|c|}
\hline Variables & $\begin{array}{l}\text { Total } \\
n=1537\end{array}$ & $\begin{array}{l}\text { Warao } \\
n=583 \\
n(\%)\end{array}$ & $\begin{array}{l}\text { Chaima } \\
n=692 \\
n(\%)\end{array}$ & $\begin{array}{l}\text { Kari'ña } \\
n=262 \\
n(\%)\end{array}$ & $p$ \\
\hline \multicolumn{6}{|l|}{ Social-demographics } \\
\hline Age, average $(\mathrm{SD})^{\mathrm{a}}$ & $41.4(17.5)$ & $37.9(15.6)$ & $44.2(18.2)$ & $41.5(18.4)$ & $<0.001$ \\
\hline Gender (female), $n(\%)$ & $943(61.3)$ & $352(60.3)$ & $416(60.1)$ & $175(66.7)$ & 0.130 \\
\hline Schooling average $(\mathrm{SD})^{\mathrm{a}}$ & $4.5(4.4)$ & $2.1(3.0)$ & $5.5(4.3)$ & $7.3(4.9)$ & $<0.001$ \\
\hline \multicolumn{6}{|l|}{ Language, $n(\%)$} \\
\hline Spanish & $1429(92.7)$ & $479(82.1)$ & $691(99.8)$ & $259(98.8)$ & $<0.001$ \\
\hline Indigenous language & $621(40.4)$ & $567(97.2)$ & $4(0.5)$ & $50(19.0)$ & $<0.001$ \\
\hline \multicolumn{6}{|l|}{ Kinship n (\%) } \\
\hline Indigenous father & $1306(84.9)$ & $537(92.1)$ & $571(82.5)$ & $198(75.5)$ & $<0.001$ \\
\hline Indigenous mother & $1437(93.4)$ & $574(98.4)$ & $645(93.2)$ & $218(83.2)$ & $<0.001$ \\
\hline \multicolumn{6}{|l|}{ Physical activity, $n$ (\%) } \\
\hline Load over $4 \mathrm{~kg}(8.82 \mathrm{lb})$ & $345(22.4)$ & $283(48.5)$ & $13(1.8)$ & 49 (18.7) & $<0.001$ \\
\hline Repeatability & $486(31.6)$ & $149(25.5)$ & $268(38.7)$ & $69(26.3)$ & $<0.001$ \\
\hline \multicolumn{6}{|l|}{ MSK pain, $n(\%)$} \\
\hline MSK pain 7 days, $n(\%)$ & $505(32.8)$ & $146(25.0)$ & $289(41.7)$ & $70(26.7)$ & $<0.001$ \\
\hline \multicolumn{6}{|l|}{ Intensity, $n(\%)$} \\
\hline No pain & $195(38.5)$ & $23(15.7)$ & $172(59.5)$ & - & $<0.001$ \\
\hline Minimal pain & $231(45.6)$ & $76(52.0)$ & $115(39.7)$ & $40(57.1)$ & $<0.001$ \\
\hline Strong pain & $68(13.4)$ & $41(28.0)$ & $1(0.3)$ & $26(37.1)$ & $<0.001$ \\
\hline Intense pain & $5(0.9)$ & $1(0.6)$ & - & $4(5.7)$ & - \\
\hline Historic MSK pain, $n(\%)$ & $584(38.0)$ & $160(27.4)$ & $319(46.1)$ & $105(40.0)$ & $<0.001$ \\
\hline Intensity, $n(\%) \mathrm{b}$ & $n=583^{*}$ & $n=159^{*}$ & & & \\
\hline No pain & $149(25.5)$ & $21(13.2)$ & $128(40.1)$ & - & $<0.001$ \\
\hline Minimal pain & $358(61.4)$ & $98(61.6)$ & $191(59.8)$ & $69(65.7)$ & - \\
\hline Strong pain & $4(0.6)$ & $1(0.6)$ & - & $3(2.8)$ & - \\
\hline Intense pain & $72(12.3)$ & $39(24.5)$ & - & $33(32.3)$ & $<0.001$ \\
\hline Functional capacity & $0(0-0.2)$ & $0(0-0.2)$ & $0.2(00.6)$ & $0(0-0)$ & $<0.001$ \\
\hline \multicolumn{6}{|l|}{$\begin{array}{l}(\mathrm{HAQ}) \text { median (RIQ) })^{\mathrm{b}} \\
\text { Functional limitation, } n(\%)\end{array}$} \\
\hline With no limitation & $431(68.0)$ & $98(68.0)$ & $200(70.4)$ & $44(62.8)$ & \\
\hline Limitation in the past & $148(23.3)$ & $27(18.7)$ & $73(17.1)$ & $12(17.1)$ & \\
\hline Current limitation & $54(8.5)$ & $19(13.1)$ & $11(3.8)$ & $14(20.0)$ & $<0.001$ \\
\hline Help care seeking for MSK complaint, $n(\%)$ & $n=525$ & & & & \\
\hline No attention & $150(28.5)$ & $112(58.9)$ & $4(1.7)$ & $34(31.4)$ & \\
\hline Medical & $250(47.6)$ & - & $222(97.8)$ & $28(25.9)$ & \\
\hline Health center & $30(5.7)$ & $30(15.7)$ & - & - & \\
\hline Self-medication & $1(0.1)$ & - & $1(0.4)$ & - & \\
\hline Traditional medicine & $13(2.4)$ & $11(5.7)$ & - & $2(1.8)$ & \\
\hline Others & $81(15.4)$ & $37(19.4)$ & & $44(40.7)$ & $<0.001$ \\
\hline Treatment for MSK complaint, $n(\%)$ & $354(23.0)$ & $63(32.8)$ & $225(66.9)$ & $63(55.7)$ & $<0.001$ \\
\hline Coping MSK complaint, $n(\%)$ & & $n=192$ & $n=337$ & $n=113$ & \\
\hline Not adapted & $109(16.9)$ & $34(17.7)$ & $48(14.2)$ & $27(23.8)$ & $<0.001$ \\
\hline Adapted & $533(83.0)$ & $158(82.2)$ & $289(85.7)$ & $86(76.1)$ & - \\
\hline
\end{tabular}

MSK musculoskeletal, HAQ Health Assessment Questionnaire, IQR interquartile range (25-75\%), SD standard deviation

${ }^{\text {a }}$ ANOVA Bonferroni test

${ }^{\mathrm{b}}$ Kruskal-Wallis test 
Fig. 1 Musculoskeletal pain places in the last 7 days

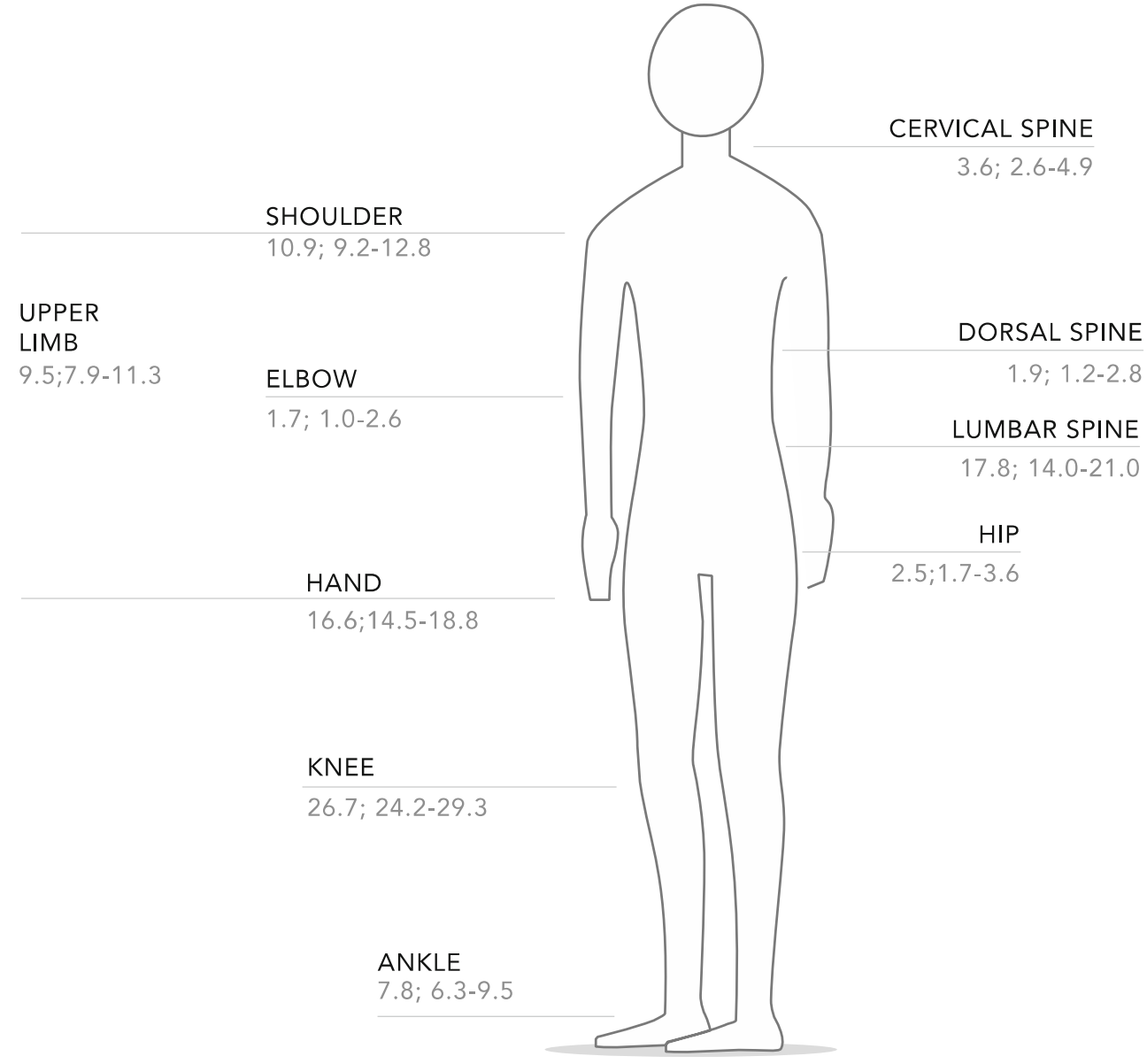

positive cases, a diagnosis of rheumatic disease was established in 545 (85\%; Fig. 2).

\section{Prevalence of rheumatic diseases}

The prevalence of specific inflammatory rheumatic diseases in the three communities was as follows: osteoarthritis, $14.1 \%$; back pain, $12.4 \%$; RRPS, $9.7 \%$; undifferentiated arthritis, $1.5 \%$; rheumatoid arthritis, $1.1 \%$; and fibromyalgia, $0.5 \%$. The differences in prevalence between the communities are presented in Table 3.

Mean age and sex ratio varied according to type of rheumatic disease. Osteoarthritis was more common in women (62.6\%), and mean age was 62.4 years, while lumbar pain was more common in men $(52.6 \%)$, and mean age was 40.5 years old. Most patients with rheumatoid arthritis adapted to pain $(87.5 \%)$ and disability $(26.6 \%)$, as shown in Table 4.

\section{Discussion}

In this study, the prevalence of MSK pain in the last 7 days was $32.9 \%$, which was higher than that previously reported $(22.4 \%)$ in the Mestizo urban population of Monagas State,
Venezuela [32], and similar to that reported in Australian aboriginals (33\%) [33]. The differences in prevalence reported by the three Venezuelan indigenous groups were likely related to different characteristics in their habits, habitat, attitude to health, and ways of dealing with illness and pain.

The Chaima had a higher prevalence of recent (41.7\%) and historical (46.1\%) pain, but lower current functional limitation (3.8\%), compared with the Warao and Kari'ña groups. Customs and language barriers appeared to affect pain perception among the groups, while the Warao and Kari'ña groups reported greater pain intensity, the Chaima, perhaps because of their more Westernized customs, showed greater concern in solving their health problems, with $97.8 \%$ seeking medical care and treatment for their ailments. There was a significant difference between the three indigenous groups in their reported physical activity, which was related to the work performed by each ethnic type and their communities' geographic location.

The knees were the most common articular region of pain, followed by the lumbar spine. These findings were similar to those reported in a non-indigenous population of Monagas State [32], in urban populations in Latin American countries such as Mexico [34] and Peru [35], and in the urban population of Shanghai, China [36]. 
Fig. 2 Rheumatic diseases detection

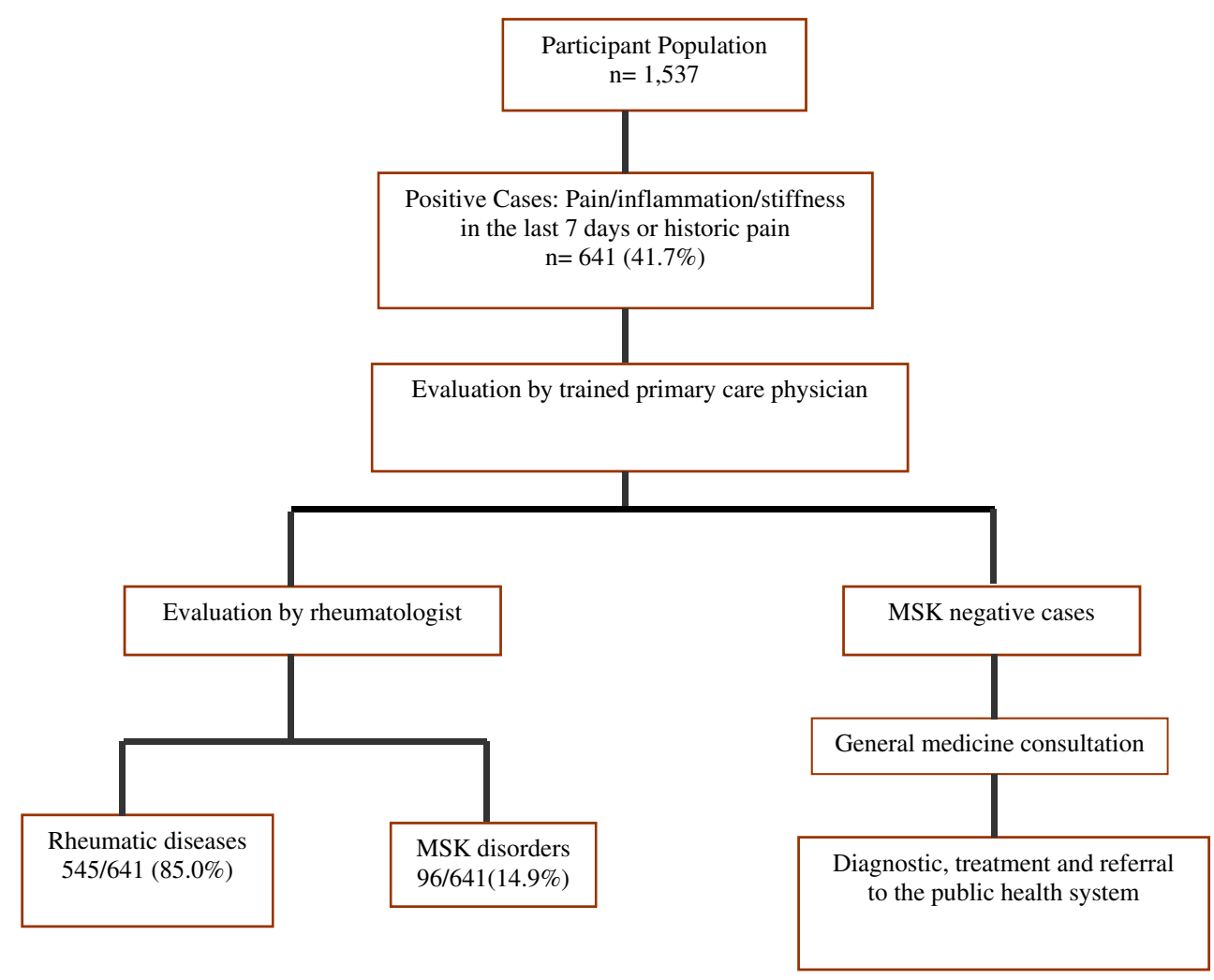

The Chaima group had a higher prevalence of rheumatic diseases; osteoarthritis was present in $18.3 \%$, similar to that reported in aboriginal Australians (18\%) [32]. The prevalence of back pain and RRPS was higher in all three groups than reported in Australian aborigines [32]. The prevalence of rheumatoid arthritis in the Chaima group (2.0\%) was higher than that in the Warao $(0.5 \%)$ and Kari'ña $(0 \%)$ groups, higher than that reported in the Kaqchiquel ethnic group in Guatemala $(0.53 \%)$ [37], similar to that recorded in a nonindigenous group in Tucumán, Argentina (1.97\%) [38], but lower than that estimated in an urban population of Yucatan, Mexico (2.8\%) [39]. Other rheumatic diseases such as systemic lupus erythematosus had only been reported in the Chaima group $(0.1 \%)$, while none had been reported in Australian aborigines, the Kaqchiquel ethnic group in Guatemala, and Latin American indigenous groups [2]. Chaima territory had some colonization by Europeans predominantly of Italian origin; therefore, it is possible that interbreeding resulted in a higher hereditary predisposition to rheumatic diseases. Specific studies of the Chaima population, including genetic factors, are needed in order to establish causal links.

The most frequent comorbidity in all three ethnic groups was dental caries $(44.0 \%)$ followed by parasitic diseases $(16.9 \%)$. In addition, a high consumption of alcohol $(13.9 \%)$ and tobacco $(13 \%)$ was recorded. There were lower prevalences of hypertension and diabetes mellitus than in the indigenous population of Guatemala [37]. However, the Chaima (16.6\%) and Kari'ña (17.5\%) groups showed a higher prevalence of hypertension than in the Warao group $(1.2 \%)$, probably related to their more Westernized lifestyles. The Warao ethnic group has preserved their traditions and customs better.

Patients with osteoarthritis were predominantly female $(62.6 \%)$ and mean age was 62.4 years, compared with $84.1 \%$ and 64 years, respectively, in Venezuelan nonindigenous patients [40]. Low back pain was more common in young men, and as in the group with osteoarthritis, showed high adaptation to pain and little limitation on their everyday lives. Rheumatoid arthritis and undifferentiated arthritis predominated in women ( $87.5 \%$; mean age, 83.3 years), below that reported in Chilean patients (Mapuches) [38].

This is the first study conducted in Venezuelan indigenous populations of the prevalence of MSK disorders and rheumatic diseases, and the methodology applied allowed us to obtain reliable results, which will be submitted to the pertinent health authorities. The results give some indication of the public health needs of the communities, and any policies should consider the epidemiological, cultural, and language differences of each ethnic group.

Venezuela was declared an illiteracy-free country by Unesco in 2003 [41], its population has free access to health and education, and the overall schooling rate stands at $93.6 \%$, but only $69.5 \%$ of the indigenous population of Monagas state is literate. There are few institutions for formal education within the indigenous geographical area (seven primary education centers), and a mean schooling of 4.5 years was found 
Table 3 Rheumatic diseases prevalence in the Warao, Chaima, and Kari'ña indigenous groups

\begin{tabular}{|c|c|c|c|c|c|}
\hline Rheumatic diseases & $\begin{array}{l}\text { Total (1537) } \\
(\% \text {; IC } 95 \%)\end{array}$ & $\begin{array}{l}\text { Warao } n=583 \\
(\% ; \text { IC } 95 \%)\end{array}$ & $\begin{array}{l}\text { Chaima } n=692) \\
(\% \text {; IC } 95 \%)\end{array}$ & $\begin{array}{l}\text { Kari'ña } n=262 \\
(\% \text {; IC } 95 \%)\end{array}$ & $p$ \\
\hline Osteoarthritis & $217(14.1 ; 12.4-15.9)$ & $49(8.4 ; 6.2-10.9)$ & $127(18.3 ; 15.5-21.4)$ & $41(15.6 ; 11.4-20.6)$ & $<0.001$ \\
\hline Back pain & $192(12.4 ; 10.8-14.2)$ & $81(13.8 ; 11.1-16.9)$ & $86(12.4 ; 10.0-15.1)$ & $25(9.5 ; 6.2-13.7)$ & 0.2 \\
\hline RRPS $^{\mathrm{a}}$ & $150(9.7 ; 8.3-11.3)$ & $44(7.5 ; 5.5-9.9)$ & $74(10.6 ; 8.4-13.2)$ & $32(12.2 ; 8.5-16.8)$ & 0.05 \\
\hline Undifferentiated arthritis & $24(1.5 ; 1.0-2.3)$ & $5(0.8 ; 0.2-9.9)$ & $16(2.3 ; 1.3-3.7)$ & $3(1.1 ; 0.2-3.3)$ & 0.09 \\
\hline Rheumatoid arthritis ${ }^{\mathrm{b}}$ & $17(1.1 ; 0.6-1.7)$ & $3(0.5 ; 0.1-1.4)$ & $14(2.0 ; 1.1-3.3)$ & - & $<0.001$ \\
\hline Fibromyalgia & $9(0.5 ; 0.2-1.1)$ & - & $8(1.1 ; 0.5-2.2)$ & $1(0.3 ; 0.0009-2.1)$ & 0.02 \\
\hline Spondylo-Arthritis ${ }^{\mathrm{c}}$ & $7(0.4 ; 0.1-0.9)$ & - & $5(0.7 ; 0.2-1.6)$ & $2(0.7 ; 0.09-2.7)$ & 0.1 \\
\hline Gout & $5(0.3 ; 0.1-0.7)$ & $1(0.1 ; 0.004-0.9)$ & $3(0.4 ; 0.08-1.2)$ & $1(0.3 ; 0.009-2.1)$ & 0.1 \\
\hline Systemic lupus erythematosus & $1(0.06 ; 0.001-0.3)$ & - & $1(0.1 ; 0.003-0.8)$ & - & - \\
\hline Scleroderma & $1(0.06 ; 0.001-0.3)$ & - & - & $1(0.3,0.009-2.1)$ & - \\
\hline MSK ailments & $100(6.5 ; 5.3-7.8)$ & $23(3.9 ; 2.5-5.8)$ & $53(7.6 ; 5.7-9.8)$ & $24(9.1 ; 5.9-13.3)$ & 0.004 \\
\hline
\end{tabular}

${ }^{a}$ Rheumatic regional pain syndromes

${ }^{\mathrm{b}}$ A Juvenile idiopathic arthritis was included

${ }^{\mathrm{c}}$ Two ankylosing spondylitis, four psoriatic arthritis, and one undifferentiated spondyloarthritis

in the present study, resulting in little professional or technical expertise in the indigenous population (Table 1). There were also limitations in the approach to health issues, determined by cultural aspects, difficult health care access for some communities, and insufficient hospital facilities in the communities.
This study had some limitations, such as operational and logistical constraints, because some communities were very remote in quite inaccessible places. There was overrepresentation of women, especially in Kari'ña communities. The reasons for this selection bias related to the following. (1)
Table 4 Social-demographic characteristics and most prevalent rheumatic diseases

\begin{tabular}{|c|c|c|c|c|}
\hline Variables & $\begin{array}{l}\text { Osteoarthritis } \\
n=217\end{array}$ & $\begin{array}{l}\text { Back pain } \\
n=192\end{array}$ & $\begin{array}{l}\text { Rheumatoid } \\
\text { arthritis } \\
n=17\end{array}$ & $\begin{array}{l}\text { Undifferentiated } \\
\text { arthritis } \\
n=24\end{array}$ \\
\hline Age, average (SD) & $62.4(14.2)$ & $\begin{array}{l}40.5 \\
\quad(14.4)\end{array}$ & $54.3(16.5)$ & $37.5(11.6)$ \\
\hline Gender (female), $n(\%)$ & $136(62.6)$ & $91(47.4)$ & $14(87.5)$ & $20(83.3)$ \\
\hline Schooling median (IQR) & $2(0-4)$ & $4(0-6)$ & $1.5(0-5)$ & $5(0-8)$ \\
\hline Indigenous language, $n(\%)$ & $59(27.1)$ & $80(41.6)$ & $3(18.5)$ & $6(25.0)$ \\
\hline Load over $4 \mathrm{~kg}$ & $83(38.2)$ & $76(39.5)$ & $2(12.5)$ & $7(29.1)$ \\
\hline Repeatability & $37(17.0)$ & $41(21.3)$ & $3(18.5)$ & $6(25.0)$ \\
\hline $\begin{array}{l}\text { Help care seeking for MSK complaint, } n \\
\quad(\%)\end{array}$ & $n=187$ & $n=153$ & & \\
\hline No attention & $30(20.3)$ & $58(37.9)$ & - & $5(26.3)$ \\
\hline Medical & $101(55.4)$ & $54(35.2)$ & $12(80.0)$ & $12(63.1)$ \\
\hline Health Center & $9(4.9)$ & $15(9.8)$ & $3(14.0)$ & $1(5.2)$ \\
\hline Self-medication & - & $1(0.6)$ & - & - \\
\hline Traditional medicine & $6(3.3)$ & $3(1.9)$ & - & - \\
\hline Others & $29(15.9)$ & $22(14.3)$ & - & $1(5.2)$ \\
\hline \multicolumn{5}{|l|}{ Coping MSK complaint, $n(\%)$} \\
\hline Not adapted & $31(14.2)$ & $36(18.7)$ & $2(12.5)$ & $21(87.5)$ \\
\hline Adapted & $186(85.7)$ & $156(81.2)$ & $14(87.5)$ & $3(12.5)$ \\
\hline Functional limitation, $n(\%)$ & $n=216$ & $n=190$ & & \\
\hline With no limitation & $140(64.8)$ & $138(72.6)$ & $2(13.3)$ & $19(79.1)$ \\
\hline Limitation in the past & $56(25.9)$ & $39(20.5)$ & $9(60.0)$ & $2(8.3)$ \\
\hline Current limitation & $20(9.2)$ & $13(6.8)$ & $4(26.6)$ & $3(12.5)$ \\
\hline
\end{tabular}

IQR interquartile range (25-75\%), SD standard deviation 
There are greater numbers of women in homes in indigenous areas, because men in Chaima and Kari'ña communities work in the fields and many Warao men fish. (2) On Saturday, men often left to buy food or sell their products in markets outside their communities. (3) Field work was not possible on Sundays because nearly everyone went to church. Despite the strategies to avoid bias, it was not possible to avoid the above representation. Language was also a problem in the case of the Warao and required the participation of bilingual male nurses. Another limitation inherent to the cross-sectional study design was the inability to determine causality, but prevalence estimates were obtained, and this was the main objective of the study.

In conclusion, this study established that the prevalence of MSK disorders and rheumatic diseases was high in the three indigenous groups. The Chaima indigenous group reported a higher prevalence of rheumatic diseases. Osteoarthritis was most prevalent in the Kari'ña and Chaima groups, followed by low back pain, which had a high prevalence in all three groups. Rheumatoid arthritis was highest in the Chaima population. This study provides useful data for the planning of health programs adapted to take into account traditional practices of indigenous communities without violating their values or ancestral beliefs.

Acknowledgments We thank Drs. Baldo Espinoza, Moraima Salave, Audrey Sanchez, and Moisés Fernández, the anthropologist Rosa Mayo, and the natives representatives Alexander Morillo (Warao), David Belmonte (Chaima), and Engineer Mr. Luis Flores for facilitating the community work. We thank PDVSA East and SUELOPETROL for their logistical support and Bristol-Myers Laboratory of Venezuela for their financial support.

Compliance with ethical standards The study was approved by the Ethics and Research Committee of the University Hospital "Dr. Manuel Núñez Tovar" and by representatives of the indigenous communities, thus complying with the provisions of the Communities and Indigenous Peoples Organic Law of the Bolivarian Republic of Venezuela [16]. All participants were informed about the study and gave their consent for use of their anonymized data.

Disclosures None.

Open Access This article is distributed under the terms of the Creative Commons Attribution 4.0 International License (http:// creativecommons.org/licenses/by/4.0/), which permits unrestricted use, distribution, and reproduction in any medium, provided you give appropriate credit to the original author(s) and the source, provide a link to the Creative Commons license, and indicate if changes were made.

\section{References}

1. Alarcón A, Muñoz S, Kaufman J (2015) Contribution of ethnic group and socioeconomic status to degree of disability in rheumatoid arthritis in Chilean patients. Rheumatol Int 35:685-689. doi: 10.1007/s00296-014-3123
2. Peláez-Ballestas I, Sanin L, Moreno-Montoya J et al (2011) Epidemiology of the rheumatic diseases in Mexico. A study of 5 regions based on the COPCORD methodology. J Rheumatol Suppl 86:3-8. doi:10.3899/jrheum.100951

3. Herráez D, Martínez-Bueno M, Riba L et al (2013) Rheumatoid arthritis in Latin Americans enriched for Amerindian ancestry is associated with Loci in Chromosomes 1,12 and 13 and the HLA class II region. Arthritis Rheum 65:1457-1467. doi:10.1002/art. 37923

4. Gray A (1992) Entre la Integridad Cultural y la Asimilación. Conservación de la biodiversidad y su impacto sobre los pueblos indígenas. IWGIA (Grupo Internacional de Trabajo sobre Asuntos Indígenas). Doc 14. Copenhague

5. Mosonyi E (1982) Identidad Nacional y Culturas Populares. Editorial La Enseñanza Viva. Pp:237-247

6. (2012) XIII Censo General de Población y Vivienda 2011. Caracas, Venezuela. Instituto Nacional de Estadística, INE

7. (1992) Censo Indígena de Venezuela 1992. Tomo II, OCEI

8. Freire G, Tillett A (2008) Salud Indígena en Venezuela. Vol 1. Ediciones de la Dirección de Salud Indígena. $2^{\text {a }}$ edición. Caracas

9. Sangha O (2000) Epidemiology of rheumatoid arthritis. Rheumatol $39 \mathrm{~S}: 2: 3-12$

10. Gabriel S, Michaud K (2009) Epidemiological studies in incidence, prevalence, mortality and comorbidity of rheumatic disease. Arthritis Res Ther 11:229. doi:10.1186/ar2669

11. Chopra A, Saluja M, Patil et al (2002) Pain and disability, perceptions and beliefs of rural Indian population. A WHO-ILAR COPCORD Study. J Rheumatol 29:614-621, PMID 11908580

12. Dans LF, Tankeh-Torres S, Amante CM et al (1997) The prevalence of rheumatic disease in a Filipino urban population: a WHO-ILAR Study. World Health Organization. International League of Associations for Rheumatology. Community Oriented Programme for the Control of Rheumatic Disease. Rheumatology 24:1814 1819

13. Kenneth D (2005) Community oriented program for control of rheumatic diseases: studies of rheumatic diseases in the developing world. Curr Opin Rheumatol 17:153-156, PMID 15711227

14. Cheryl K (2005) The role of ethnicity in willingness to participate in rheumatoid arthritis clinical trials. J Rheumatol 32:12, PMID 16331749

15. Odutola J, Ward M (2005) Ethnic and socioeconomic disparities in health among patients with rheumatic disease. Curr Opin Rheumatol 17:147-152, PMID 15711226

16. (2005) Ley Orgánica de Pueblos y Comunidades Indígenas. República Bolivariana de Venezuela

17. Navarro C, Hernández C (2008) Pueblos Indígenas de Venezuela. Editorial Santillana, S.A. Caracas

18. Biord H, Amodio E, Mosonyi J (2001) Los Kari'ñas. Operadora Cerro Negro

19. De Civrieux M (2006) Los Chaimas del Guácharo: Etnología del Oriente de Venezuela. 1919-2003. Ministerio de Educación y Deportes. Dirección de Educación Indígena

20. Rogelio L (1997) Caripe: historia cotidiana y oralidad. Primera edición. Maturín

21. Peláez-Ballestas I, Granados Y, Silvestre A, Valls E, Stekman I, Jorfeen M, Chacón R, Pons-Estel BA (2012) Cross-cultural adaptation of community oriented program for the control of rheumatic disease methodology in Latin American indigenous population. J Clin Rheumatol 18: Supl:3. Doi: 10.1007/s00296-014-2997-z

22. Reichenheim M, Moraes C (2007) Operationalizing the crosscultural adaptation of epidemiological measurement instruments. Rev Salud Pública 41-44 PMID 17589768

23. Altman R, Alarcon G, Appelrouth D, Bloch D, Borenstein D, Brandt K et al (1990) The American College of Rheumatology criteria for the classification and reporting of osteoarthritis of the hand. Arthritis Rheum 33:1601-1610, PMID 2242058 
24. Altman R, Asch E, Bloch D, Bole G, Borenstein D, Brandt K et al (1986) Development of criteria for the classification and reporting of osteoarthritis. Classification of osteoarthritis of the knee. Diagnostic and Therapeutic Criteria Committee of the American Rheumatism Association. Arthritis Rheum 29:1039-1049, PMID: 3741515

25. Arnett FC, Edworthy SM, Bloch DA, McShane DJ, Fries JF, Cooper N et al (1998) The American Rheumatism Association 1987 revised criteria for the classification of rheumatoid arthritis. Arthritis Rheum 31:315-324, PMID 3358796

26. Wolfe F, Smythe HA, Yunus MB, Bennett RM, Bombardier C, Goldenberg DL et al (1990) The American College of Rheumatology 1990 criteria for the classification of fibromyalgia. Report of the Multicenter Criteria Committee. Arthritis Rheum 33: 160-172, PMID 2306288

27. Hochberg MC (1997) Updating the American College of Rheumatology revised criteria for the Classification of systemic lupus erythematosus. Arthritis Rheum 40:1725, PMID 9324032

28. Wallace SL, Robinson H, Masi AT, Decker JL, McCarty DJ, Yu TF (1997) Preliminary criteria for the classification of the acute arthritis of primary gout. Arthritis Rheum 20:895-900, PMID 856219

29. Van der Linden S, Valkenburg HA, Cats A (1984) Evaluation of diagnostic criteria for ankylosing spondylitis. A proposal for modification of the New York criteria. Arthritis Rheum 27:1361-1368, PMID 6231933

30. Walker-Bone K, Byng P, Linaker C, Reading I, Coggon D, Palmer $\mathrm{K}$ et al (2002) Reliability of the Southampton examination schedule for the diagnosis of upper limb disorders in the general population. Ann Rheum Dis 61:1103-1106, PMID: 12429544

31. (2004) The ICD-10 international statical classification of diseases and related health problems: 10th revision, 2nd ed. World Health Organization, Geneva

32. Granados Y, Cedeño L, Rosillo C, Peláez-Ballestas I et al (2014) Prevalence of musculoskeletal disorders and rheumatic diseases in an urban community in Monagas State, Venezuela: a COPCORD Study. Clin Rheumatol 33:1231-1238. doi:10. 1007/s10067-014-2689-9

33. Minaur N, Sawyers S, Parker J, Darmawan J (2004) Rheumatic disease in an Australian aboriginal community in North Queensland, Australia. A WHO-ILAR COPCORD survey. J Rheumatol 31:5965-5972

34. Cardiel MH, Rojas-Serrano J (2002) Community based study to estimate prevalence, burden of illness and help seeking behavior in rheumatic diseases in Mexico City. COPCORD study. Clin Exp Rheumatol 20:617-624, PMI 12412191

35. Gamboa R, Medina M, Acevedo E et al (2007) Prevalence of rheumatic disease and disability in an urban marginal Latin American population. A community based study using the COPCORD model approach. Arthritis Rheum 9:S344

36. Sheng-Ming D (2003) Prevalence of rheumatic symptoms, rheumatoid arthritis, ankylosing spondylitis and gout in Shanghai, China. J Rheumatol 30:2245-2251, PMID 14528524

37. Obregón-Ponce A, Iraheta I, Garcia-Ferrer G, Mejia B, GarciaKutzbach A (2012) Prevalence of musculoskeletal diseases in Guatemala, Central America. The COPCORD study of 2 populations. J Clin Rheumatol 18(4):170-174

38. Spindler A, Bellomio V, Berman A, Lucero E, Baigorria M et al (2002) Prevalence of rheumatoid arthritis in Tucuman, Argentina. J Rheumatol 29(6):1166-1170, PMID 12064829

39. Alvarez-Nemegyei J, Peláez-Ballestas I, Sanín L, Cardiel M, Ramírez A et al (2011) Prevalence of Musculoskeletal Pain and Rheumatic Diseases in the Southeastern Region of Mexico. A COPCORD Based Community Survey. J Rheumatol 38(S86):21-25

40. Chacón J, González N, Losada B, Hernando P, Santiago L, Rodríguez M et al (2004) Effect of knee osteoarthritis on the perception of quality of life in Venezuelan patients. Arthritis Rheum 51(3):377-382. doi:10.1002/art.20402

41. UNESCO (2015) Situación Educativa de América Latina y el Caribe Hacia una educación para todos 2015. http://www.unesco. org/new/fileadmin/MULTIMEDIA/FIELD/Santiago/pdf/situacioneducativa-mexico-2013.pdf. Accessed 22 Sept 2015 